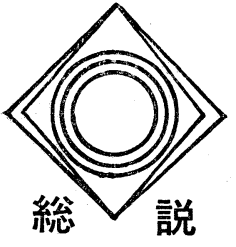

1. はじめに

最近世界的な石油危機が叫ばれるとともに，ボイラ 一用然料として石炭を使用することが要望されるよう になった。しかし，石炭燃料から石油へ転換して行っ た過去の歴史を振り返って見れば，石油から石炭へと 逆の道を歩むには経済的，技術的济解決されなければ ならない多くの問題があることは自明の所である。特 飞往時それ程大きな問題ではなかった環境に関する最 近の状況を考光れば，この面だけでる解決せ齐ばなら ない多くの問題がある。

ボイラー燃料として石炭を使用する場合，その排煙 の性状を環境問題の立場から石油の場合と比較する と,つぎのような問題点がある。

(1) 発生電力量あたりの排ガス量が多い。

（2）含有ダスト量が数十倍〜数百倍に増加する。

(3) $\mathrm{NO}_{x}$ の含有量が数倍になる。

(4) $\mathrm{SO}_{x}$ の含有量も増加することが多い。

(5) 残存酸素の量が多い。

これらのらち，排ガス量が増加することは，処理装 置が大型となり，必要触媒量が增加することによる経
日立造船秼 稲 葉 榮 也
-1980. 7. 1 受理一
費增以外に特に問題はないが，含有ダストが多いこと は，そ礼自体の処理（最終的な廃育処分も含め）がき わめて重要であるばかりでなく, $\mathrm{NO}_{x}$ 及び $\mathrm{SO}_{x}$ の処 理に対しても非常に大きい影響を与兄る。極論するな らば，石炭燃焼排煙处理の最も重要な点は含有ダスト 飞対する対策であるといって差しつか学ないと思われ る。

\section{2. 石炭焚き排煙脱硝処理プロセス}

ボイラー排煙に対する脱硝プロセスとして提案され ているものを整理すると図 1 に見られるようなプロセ スが考えられる。

石炭焚きボイラーからの $\mathrm{NO}_{x}$ 発生量は施設 の 種 類，規模によって全国一律に規制されている。その規 制值を表 $1^{3)}$ 亿示す。しかし，よく知られるように各地 方行政機関による上乗せ規制が行われて括り，実際に 許される $\mathrm{NO}_{x}$ 排出許容值は設置場所によってかなり 大幅に相違することを承知して勏かね将ならない。

図1ケース $3^{1)}$ 抢よびケース 4 はいずれる無触媒脱 硝法であり，ケース 3 はすでに実用段階（クリーン排 ガスに対し）にあるが，ケース $4^{22}$ はまだパイロット

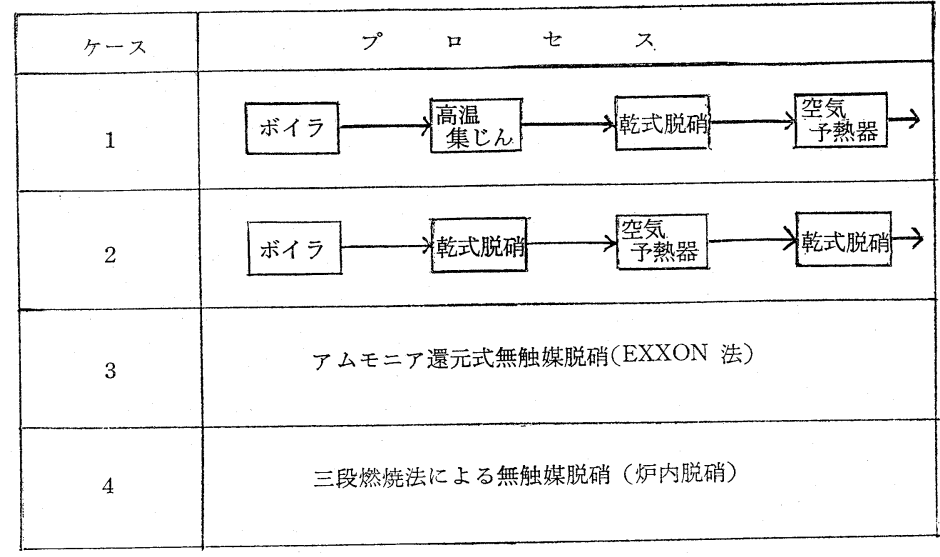

図 1 乾式脱硝プロセス

特別顧門・脱硝開発部長 : 東京都千代田区一ツ橋1-1 
表 1 石炭焚きボイラー $N \mathrm{O}_{x}$ 排出基準値新旧対照表

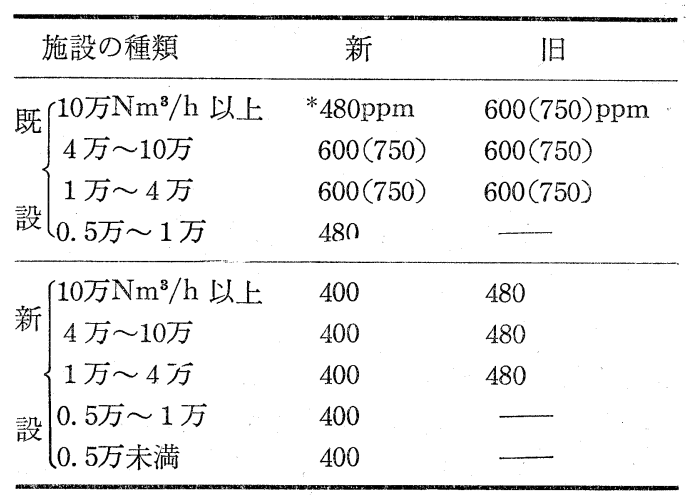

*天井バーナーは650ppm, 分割壁型は $550 \mathrm{ppm}$ （）は低品位炭の場合

プラントの段階である。現時点では, いずれの方法る 脱硝率活 $30 \sim 50 \%$ 前後と考克られ, 表 1 の規制は満足 出来たとしても，それだけでは地方行政機関による上 乗せ規制をクリヤーすることは困難であるらと思われ る。るちろんその場合でも, ケース 1 牤よび 2 の前段 処理として実施することは, 当然必要触媒量が少くて 済むことになるので有効な手段である。これらについ ては後にあらためて述べることとし，ケース 1 および ケース 2 について考光るととする。

\section{3. 排ガス含有ダストと乾式㨸触脱硝}

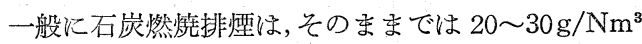
のダスト学含んでいる。したがって，そのままの状態 で乾式接触脱硝を行らためには触煤の型状扮よび使用 法を工夫することが必要となる。いろいろな工夫が提 案されているが，大別すれば，

移動床。

ダストスルー型固定床。

のいずれかを採用することとなる。

移動床を採用する研究は当初か度り多く行われた が，この方法は脱硝と同時にかなり高い脱じん効果を 期待できる反面

（1）触媒䔟惭のための附带設備の建設竇が高くつ く。

（2）必要な設置面積が大きい。

（3）附带設備運転のための動力が必要となる。

(4) 移動，節分による触媒の機械的破損口スが大。

（5）触媒層上下部のガス非流通部に和ける $\mathrm{SO}_{x}$ の 凝縮を防ぐため強制保温が必要亡なる。 などの欠点があるため, 最近の傾向は各社共涪とんぞ ダストスルー型固定床を採用する傾向仙る゙”。

一般に，石炭灰は40 50\%程度の珪酸分を含んで招
り，そのために使用条件によっては激しい摩耗現象を 特こす。一方，摩耗を避けようとして流速を遅くする 之触媒表面への附着が括こりやすく，そのための活性 低下や，触媒層の目詰りが扔こることとなる。この対 策としては,

（1）触媒層の表面を強化し，耐摩耗性を高める。

(2) 予馀じんを行う。

いずれかの対策を行うことが必要であるが，触媒活 性を低下させずに表面強度をあげることは一朝に解決 できる問題ではないため, 現在, 実用化は取りあ劣ず ケース(1)の方向にすすんでいる゙。

我々の実験から得た知見では, ダストの機壁, 触媒 表面への附着は, 高ダストの場合には $2 \mathrm{Nm} / \mathrm{sec}$ 程度 の流速です棌とんど拉こらないが，90\%程度の除じん を行った場合には $6 \mathrm{Nm} / \mathrm{sec}$ 程度まで流速をあげてる な秥はげしく和こり，附着を防止するにはさらに高い 除じんが必要であることがわかった。

この点に関して, 東京電力株が最近行った新聞発 表7)では, 高温電気集じん器を使用した場合 (除じん 率は $99.9 \%$ 程度々想像される) でも，な特微粉ダスト は強い附着傾向があり, 附着を防止するためには, 高 流速とスートブローイングの必要なことを述べてい る。同時に我ふの経験同様, 高ダストを含む排檉を直 接脱硝する場合には触媒層はもとより, 後流の空気予 熱器に执いてもダストの附着はまったく沶こらないこ とを述べている。

以上の点から考光ると, 圧倒的邱一ス(2)の方が有 利で岁ることになるが，必ずしもそらはいい切れな い。それは高温電気集じん器と低温電気集じん器の効 率の問題, 集じんされたダスト中に含まれるアムモニ ウム根の問題などの脱硝反応以外の問題があるからで ある。これらの点に関しては, 後でふれることとし, 含有ダストと触媒の関係を今少し考学て見ることとす る。表 $2^{8)}$ 以一般的な石炭燃焼灰 (フライフッシュ) の化学成分, 図 $2^{9)}$ そとの電子顕微鏡写真を示す。 図 $3^{10)}$ 飞微粉炭ボイラーダストの粒径分布を示す。図 2 抢よび図 3 からわかるよらに, ダストの粒径は燃焼 条件, 特に微粉炭燃焼時にはミルの型式および微粉度 によって大きく変動する。

ダスト濃度にもっとも大きな影響を与えるのは石炭 中の灰分であり, 灰分が多い饾どダスト濃度は当然高 くなる通常, 火炉内で生成されたダストのうち, 20〜 25\%はボイラー内で落下するので, ボイラー出口では 高品位炭の場合で $20 \mathrm{~g} / \mathrm{Nm}^{3}$ 前後, 低品位炭で $35 \mathrm{~g} /$ $\mathrm{Nm}^{3}$ 前後である。 
表 2 石炭灰（フライアッシュ）の化学成分

\begin{tabular}{ccccccccccccccccccc}
\hline & $\mathrm{SiO}_{2}$ & $\mathrm{TiO}_{2}$ & $\mathrm{Al}_{2} \mathrm{O}_{3}$ & $\mathrm{Fe}_{2} \mathrm{O}_{3}$ & $\begin{array}{c}\mathrm{B}_{2} \mathrm{O}_{3} \\
(\mathrm{ppm})\end{array}$ & $\mathrm{CaO}$ & $\mathrm{MgO}$ & $\mathrm{MnO}$ & $\mathrm{Na}_{2} \mathrm{O}$ & $\mathrm{K}_{2} \mathrm{O}$ & $\mathrm{P}_{2} \mathrm{O}_{5}$ & $\mathrm{~V}_{2} \mathrm{O}_{5}$ & $\mathrm{SO}_{3}$ & $\mathrm{C}$ & Ig. loss \\
\hline $\mathrm{A}$ & 56.93 & 0.06 & 26.12 & 5.08 & 2,340 & 3.16 & 0.83 & 0.14 & 1.41 & 1.14 & 0.91 & 0.11 & 1.01 & 1.06 & 1.13 \\
$\mathrm{~B}$ & 55.64 & 0.08 & 25.13 & 4.98 & 2,360 & 4.08 & 1.18 & 0.18 & 1.19 & 1.21 & 1.06 & 0.09 & 1.11 & 1.15 & 1.08 \\
$\mathrm{C}$ & 55.34 & 0.04 & 26.15 & 5.46 & 2,340 & 4.00 & 1.21 & 0.23 & 1.06 & 1.18 & 1.18 & 0.09 & 1.08 & 1.02 & 1.10 \\
$\mathrm{D}$ & 58.38 & 0.03 & 26.00 & 4.18 & 2,280 & 4.96 & 1.16 & 0.12 & 1.31 & 0.88 & 1.41 & 0.03 & 0.27 & 0.43 & 0.21 \\
$\mathrm{E}$ & 54.94 & 0.01 & 24.50 & 7.58 & 2,480 & 4.96 & 2.41 & 0.16 & 0.58 & 0.61 & 0.68 & 0.06 & 0.76 & 1.06 & 1.18 \\
$\mathrm{~F}$ & 54.33 & 0.01 & 22.40 & 7.26 & 2,410 & 7.31 & 2.31 & 0.11 & 0.73 & 0.88 & 0.82 & 0.07 & 0.89 & 1.00 & 1.28 \\
$\mathrm{G}$ & 54.90 & 0.02 & 22.10 & 8.68 & 2,610 & 5.83 & 2.01 & 0.16 & 0.53 & 0.93 & 0.86 & 0.05 & 1.08 & 1.11 & 1.26 \\
$\mathrm{H}$ & 53.90 & 0.01 & 22.61 & 8.46 & 2,560 & 5.26 & 1.01 & 0.11 & 1.73 & 1.23 & 1.11 & 0.08 & 1.16 & 1.46 & 1.26 \\
$\mathrm{I}$ & 54.13 & 0.01 & 24.00 & 7.61 & 2,580 & 4.80 & 1.14 & 0.08 & 1.67 & 1.43 & 1.08 & 0.05 & 1.04 & 1.01 & 1.36 \\
$\mathrm{~J}$ & 55.83 & 0.02 & 22.41 & 6.90 & 2,490 & 5.21 & 1.94 & 0.14 & 1.43 & 1.03 & 0.91 & 0.07 & 1.11 & 1.14 & 1.36 \\
$\mathrm{~K}$ & 55.16 & 0.02 & 30.50 & 4.56 & 2,450 & 2.11 & 0.92 & 0.07 & 0.68 & 1.00 & 0.99 & 0.09 & 1.06 & 1.11 & 1.12 \\
$\mathrm{~L}$ & 55.35 & 0.02 & 30.69 & 4.13 & 2,510 & 2.28 & 0.96 & 0.08 & 0.61 & 0.98 & 1.06 & 0.06 & 1.03 & 1.09 & 1.06 \\
$\mathrm{M}$ & 57.11 & 0.02 & 29.18 & 4.38 & 2,380 & 1.18 & 0.92 & 0.06 & 0.76 & 1.12 & 1.16 & 0.48 & 1.29 & 1.43 & 0.66 \\
$\mathrm{~N}$ & 56.63 & 0.01 & 28.40 & 3.24 & 2,510 & 1.83 & 1.09 & 0.04 & 0.58 & 1.02 & 0.96 & 0.16 & 1.28 & 1.31 & 0.88 \\
$\mathrm{O}$ & 56.24 & 0.01 & 27.81 & 3.43 & 2,410 & 2.06 & 0.86 & 0.05 & 1.01 & 1.11 & 1.29 & 0.16 & 1.18 & 1.40 & 0.68 \\
$\mathrm{P}$ & 59.73 & 0.01 & 29.13 & 3.11 & 2,240 & 1.28 & 1.16 & 0.08 & 1.16 & 1.38 & 1.68 & 0.01 & 0.21 & 0.41 & 0.10 \\
\hline 米で & $17.3 \sim$ & $0 \sim$ & $9.81 \sim$ & $2.0 \sim$ & $0.12 \sim$ & $0.12 \sim$ & $0.06 \sim$ & & $0.2 \sim$ & $2.8 \sim$ & $0.07 \sim$ & $0.12 \sim$ & $0.37 \sim$ & \\
の例* & 63.6 & 2.8 & 58.4 & 26.8 & & 14.73 & 4.77 & & 0.9 & 3.0 & 47.2 & 24.33 & 36.2 & \\
\hline
\end{tabular}
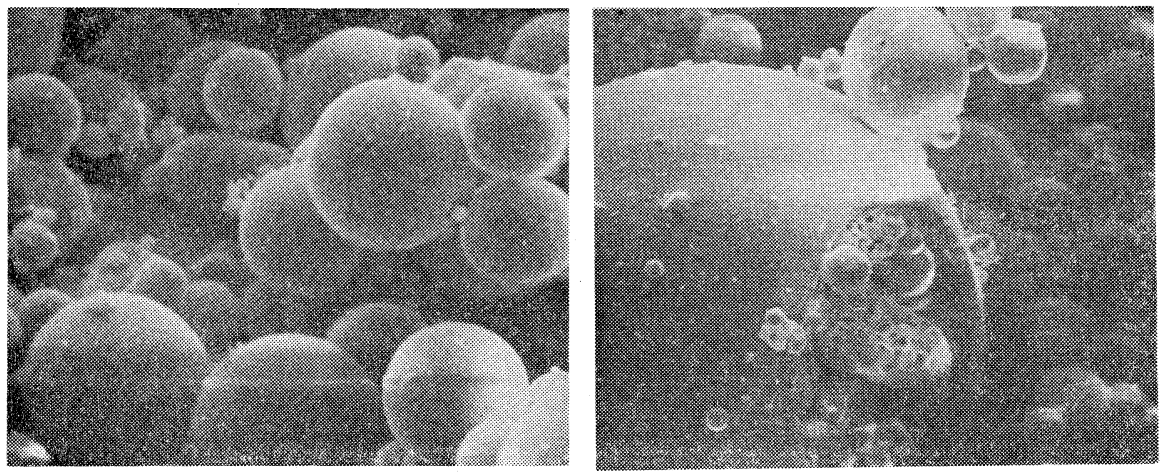

図 2 ダストの電子顕微写真 $(\times 1,800)$

一般に，ダストの粒子径が $44 \mu$ 以上のものは，不 完全然焼等によって生成されたもので不定形である が， $44 \mu$ 以下の粒子は完全燃焼によって，いったん灰 分が熔融し，乞れが温度低下によって凝固し生成した ものと考兄られ，きれいな球状になっている。（図 2 参照) 図 $4^{10}$ にフライアッシュの粒子径と附着力の関 係を示す。四から和かるように，フライアッシュの付 着力は $10 \mu$ 程度以下から急激汇附着力が增加する。 この事は, 我々の経験とも, 亲た前述した東京電力株 の発表ともよく一致する。

ダストの附着性を示す指標としてフォーリング
(Fouling) 指数 ${ }^{11}$ がある。これは米国 $\mathrm{B} \& \mathrm{~W}$ 社で開 発されたフォーリング特性に対するボイラー設計上の 指針で西るが，脱硝用触媒への石炭灰附着に対する関 係も良く説明することが出来る。（表 3 参照）

図 $5^{11}$ にダスト中に含末れる $\mathrm{Na}$ 分之附着性の関係 を, 表 $4^{12)}$ に実験で得た結果を示す。同じように高ダ ストの委, 同一形状の触媒を用い, 同一条件 (反応 温度, $\mathrm{NH}_{3} / \mathrm{NO}$ モル比，LV, AV など) で脱硝を行 った場合, ケース A-1 はスートブローイングなしで もまったく压損上昇が見られないにもかかわらず，ヶ ースBは徐々に圧損が上昇し，遂には閉塞が扣こる。 


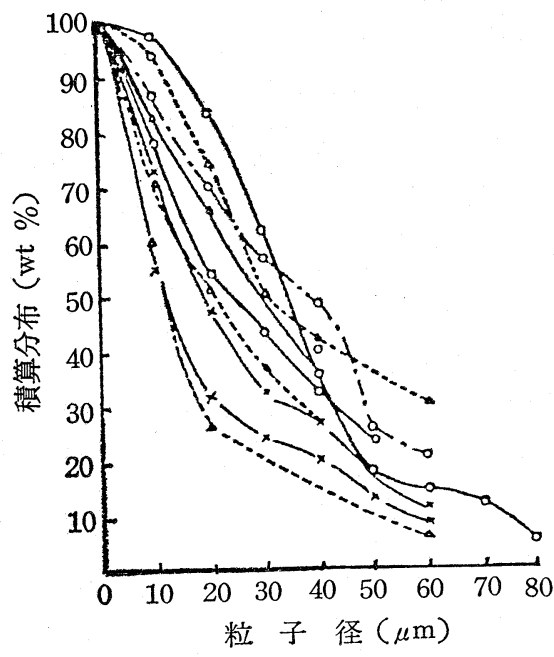

図 3 微粉炭ボイラーダストの粒径分布

これを防止するには流速を高くするとか，強いスート ブローイングを行らことが必要となる。このことは単 にダスト量, 粒子径では理解しがたい現象であるが, 表 4 の結果に表 3 をあてはめて見ると, ケース A-1 はフォーリングが少なく，ケースBはフォーリングが 非常に多いといら結果が得られ, 上記現象をよく理解 することが出来る。また, ケース A-1 と同一ガス源 であるにもかかわらず，サイクロンを通して $95 \%$ 脱じ んしたケース A-2 は触媒表面への灰附着がおこり易 く,スートブローイングなしでは, 圧損上昇, マスキ ングによる見掛け活性の低下が和こり, 最終的には閉

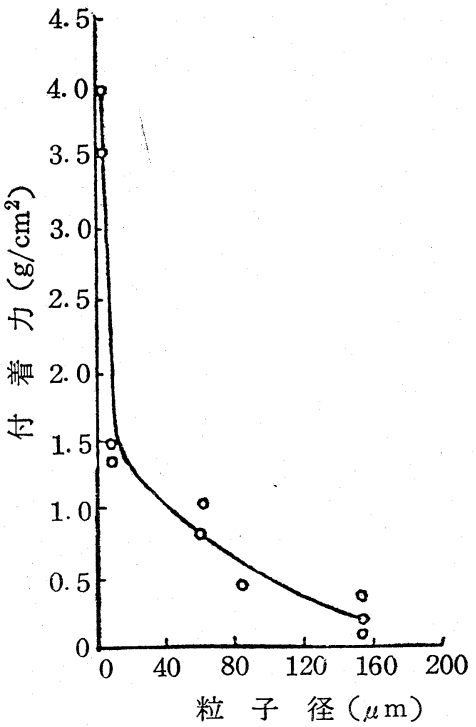

図 4 フライアッシュの付着力

塞に到ることとなる。この事実も，粒子径，フォーリ ング指数を併せて考えると，よく理解することが出来 る。

一般にダストによる触媒表面の摩耗量は次式で示す ことが出来る。

摩耗量 $\left(\mathrm{g} / \mathrm{m}^{2}\right)=\mathrm{K}^{*} \times\left[\right.$ ダスト濃度 $\left.\left(\mathrm{g} / \mathrm{Nm}^{3}\right)\right]$ ・ $[\text { 実流速 }(\mathrm{m} / \mathrm{sec})]^{2} \cdot[$ 時間 $(\mathrm{h})] \cdots(1)$

* 触媒の種類・炭種・燃焼条件等により定まる 定数

表 3 石炭灰組成とフォーリングの関連

B \& W 社で開発したフォーリング特性に対する設計上の指針である。

\begin{tabular}{|c|c|}
\hline \multicolumn{2}{|c|}{$\begin{array}{l}\text { 瀝青炭型石炭灰 (Bituminous Ash). } \mathrm{CaO}+\mathrm{MaO}<\mathrm{Fe}_{2} \mathrm{O}_{3} \\
\operatorname{Rf}\left(\text { フォーリング指数) }=\frac{\mathrm{CaO}+\mathrm{MgO}+\mathrm{Fe}_{2} \mathrm{O}_{3}+\mathrm{Na}_{2} \mathrm{O}+\mathrm{K}_{2} \mathrm{O}}{\mathrm{SiO}_{2}+\mathrm{Al}_{2} \mathrm{O}_{3}+\mathrm{T}_{1} \mathrm{O}_{2}} \times \mathrm{S}\right.\end{array}$} \\
\hline フォーリングの区分 & 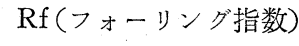 \\
\hline Low（少ない） & 0.2 以下 \\
\hline Medium（中程度） & $0.2 \sim 0.5$ \\
\hline High (多小) & $0.5 \sim 1.0$ \\
\hline Severe（非常に多い） & 1.0以上 \\
\hline \multicolumn{2}{|c|}{ 褐炭型石炭灰 (Lignitic Ash). $\mathrm{CaO}+\mathrm{MgO}>\mathrm{Fe}_{2} \mathrm{O}_{3}$} \\
\hline フォーリングの区分 & $\mathrm{Na}_{2} \mathrm{O} . \%$ \\
\hline Medium（中程度） & 3 以下 \\
\hline High (多W) & $3 \sim 6$ \\
\hline Severe (非常に多い) & 6 以上 \\
\hline
\end{tabular}




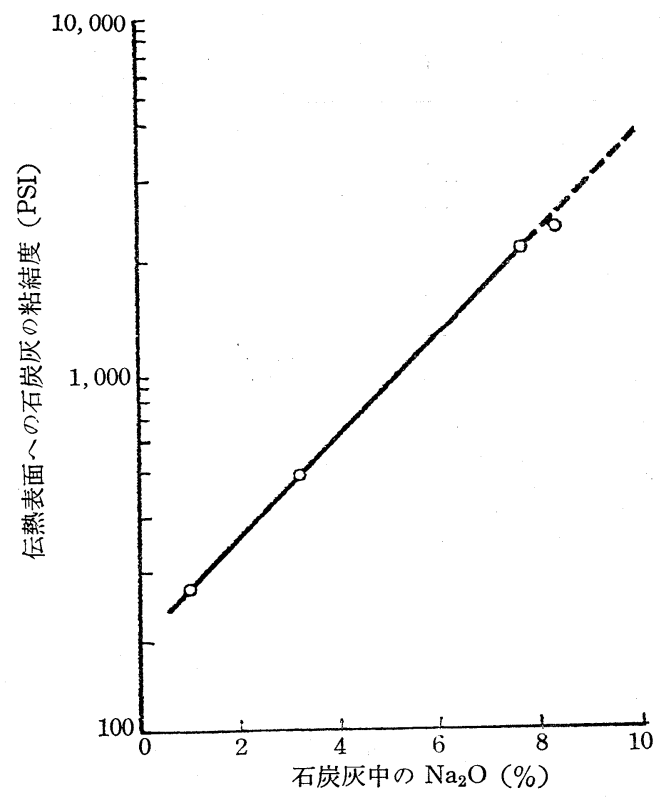

石炭灰中の $\mathrm{Na}_{2} \mathrm{O}$ が増加することによって，灰の 付着強度が増加し, 除去しにくくなってくる。

\section{図 5 伝熱表面への灰付着に対する $\mathrm{Na}_{2} \mathrm{O}$} の影響

摩耗量は当然炭種によって異なるわけであるが，同 一炭種である表 4 ケース A-1 と A-2 の場合を比較

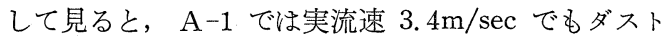

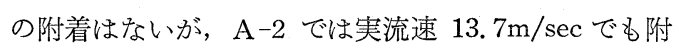
着を抗こすことから，附着を防止するためにはさらに 高流速で流すか, あるいは強いスートブローイングを 行ら必要があることになる。したがって, 触媒表面の 摩耗は単にダスト量のみで判断することは出来ない。

(1)式に和けるKの值は触媒によってかなりの差があ り，我々の実験結果から見ると $10^{-3} \sim 10^{-5}$ の単位で ある。従って，他の条件がまったく同じであっても触 媒の種類によって摩耗量は大きく異なることとなる。 触媒の密度をあげることによって, その表面強度を強 くすることは比較的容易と考えられるが，その場合に は活性は低下する傾向にある。従って活性を低下させ ることなく表面摩耗強度を高めることは, やさしい問 題ではないが石炭排煙脱硝をより容易により効率的 に，より経済的に実施するためには，今後是非とも解 決されねばならない問題である。

\section{4. 排出ガス量と $\mathrm{NO}_{\boldsymbol{x}}$ 規制値}

表 $5^{14)}$ に示すように, 現在の規制値は燃料の種類に よってその排出濃度を規制している。このような差が
表 4 実施例

\begin{tabular}{|c|c|c|c|c|c|c|c|}
\hline \multirow{3}{*}{\multicolumn{2}{|c|}{$\frac{\text { ケ }}{\text { 採 取 }}$}} & - & ス & \multicolumn{2}{|c|}{$A-1$} & $A-2$ & $\mathrm{~B}$ \\
\hline & & & & $\mathrm{ECO}$ & & CYCLON & $\mathrm{ECO}$ \\
\hline & & 場 & 所 & 出 & 口 & 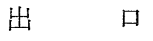 & 出口 \\
\hline \multirow{4}{*}{$\begin{array}{l}\text { 石 } \\
\text { 炭 } \\
\text { 分 } \\
\frac{1}{0}\end{array}$} & & 有 水 & 分 & \multicolumn{3}{|c|}{4.2} & 4.9 \\
\hline & 灰 & & 分 & \multicolumn{3}{|c|}{16.0} & 12.1 \\
\hline & 炭 & 素 & 分 & \multicolumn{3}{|c|}{63.7} & \\
\hline & 硫 & 黄 & 分 & \multicolumn{3}{|c|}{0.6} & 1. 24 \\
\hline \multirow{5}{*}{$\begin{array}{l}7 \\
\text { ラ } \\
1 \\
> \\
y \\
シ \\
\text { ב }\end{array}$} & & $\mathrm{SiO}_{2}$ & & \multicolumn{2}{|l|}{46.5} & 45.4 & 50.5 \\
\hline & & $\mathrm{Al}_{2} \mathrm{O}_{3}$ & & \multicolumn{2}{|l|}{23.6} & 21.2 & 29.1 \\
\hline & & $\mathrm{Fe}_{2} \mathrm{O}_{3}$ & & \multicolumn{2}{|l|}{7.3} & 5.1 & 11.0 \\
\hline & & $\mathrm{Na}_{2} \mathrm{O}$ & & \multicolumn{2}{|l|}{0.05} & 0.18 & 0.07 \\
\hline & & $\mathrm{K}_{2} \mathrm{O}$ & & \multicolumn{2}{|l|}{0.05} & 0.10 & 0.24 \\
\hline 分 & & $\mathrm{MgO}$ & & \multicolumn{2}{|l|}{2.5} & 1.8 & 0.76 \\
\hline 值 & & $\mathrm{CaO}$ & & \multicolumn{2}{|l|}{7.3} & 2.7 & 0.20 \\
\hline$\%$ & & $\mathrm{SO}_{4}$ & & \multicolumn{2}{|l|}{1.4} & 7.2 & 5.1 \\
\hline & & $\mathrm{NH}_{3}$ & & \multicolumn{2}{|c|}{0.002} & 0.04 & - \\
\hline \multicolumn{4}{|c|}{ フライアッシュ濃度 } & \multicolumn{2}{|l|}{20.0} & 1.0 & 16.0 \\
\hline \multicolumn{4}{|c|}{ フォーリング 指 数 } & \multicolumn{2}{|c|}{0.115} & 0.356 & 0.262 \\
\hline \multicolumn{4}{|c|}{ 平均粒子径 $(\mu)$} & \multicolumn{2}{|l|}{2.3} & 0.7 & 3.1 \\
\hline
\end{tabular}

あるのは然料によって $\mathrm{NO}_{x}$ 低減技術に難易があり, 易しく完成されたものにはきびしく，難度が高く，技 術的に不充分と思われるものに対しては可能と思われ る值にきめられたものである。しかし，純粋に環境問 題として捕光る場合には然料の種類をとわず同一でな ければならない。したがって，この值は今後技術の進 歩とともに改訂される暫定的なものであると考えてお かねばならない。また，遠からず総量規制が導入され るであろらことを考光れば，技術的に可能となったと 判定された時点では, 発電量当りの排出ガス量の多い 石炭燃焼の場合には排出 $\mathrm{NO} x$ は, 他燃料の場合に比 し低レベルを要求されることもありらると思われる。

\section{NO $x$ 含有量が高い問題}

$\mathrm{NH}_{3}$ 学還元剂とする脱硝反応は凝一次反応であ る15)。したがって，同一脱硝率を得るためには図 $6^{16)}$ に見られるよらに，含有濃度の如何に拘らず同一触媒 量でよいが，排出濃度を同一にするためには当然多量 の触媒と多量の $\mathrm{NH}_{3}$ が必要となる。たとえば， $\mathrm{NO} x$ 濃度がそれぞれ 400ppm 及び 150ppm の排ガスを脱 硝して同じ $20 \mathrm{ppm}$ にするために必要な脱硝率はそれ ぞれ95\%，86.7\%となり，必要触媒量は後者は前者の 約 $67 \%$ て良いことになる。また $\mathrm{NH}_{3}$ の必要量は 37.5 \%で良いことになる。 
表 5 燃料の種類と $\mathrm{NO}_{\boldsymbol{x}}$ 排出基集（新設の場合）

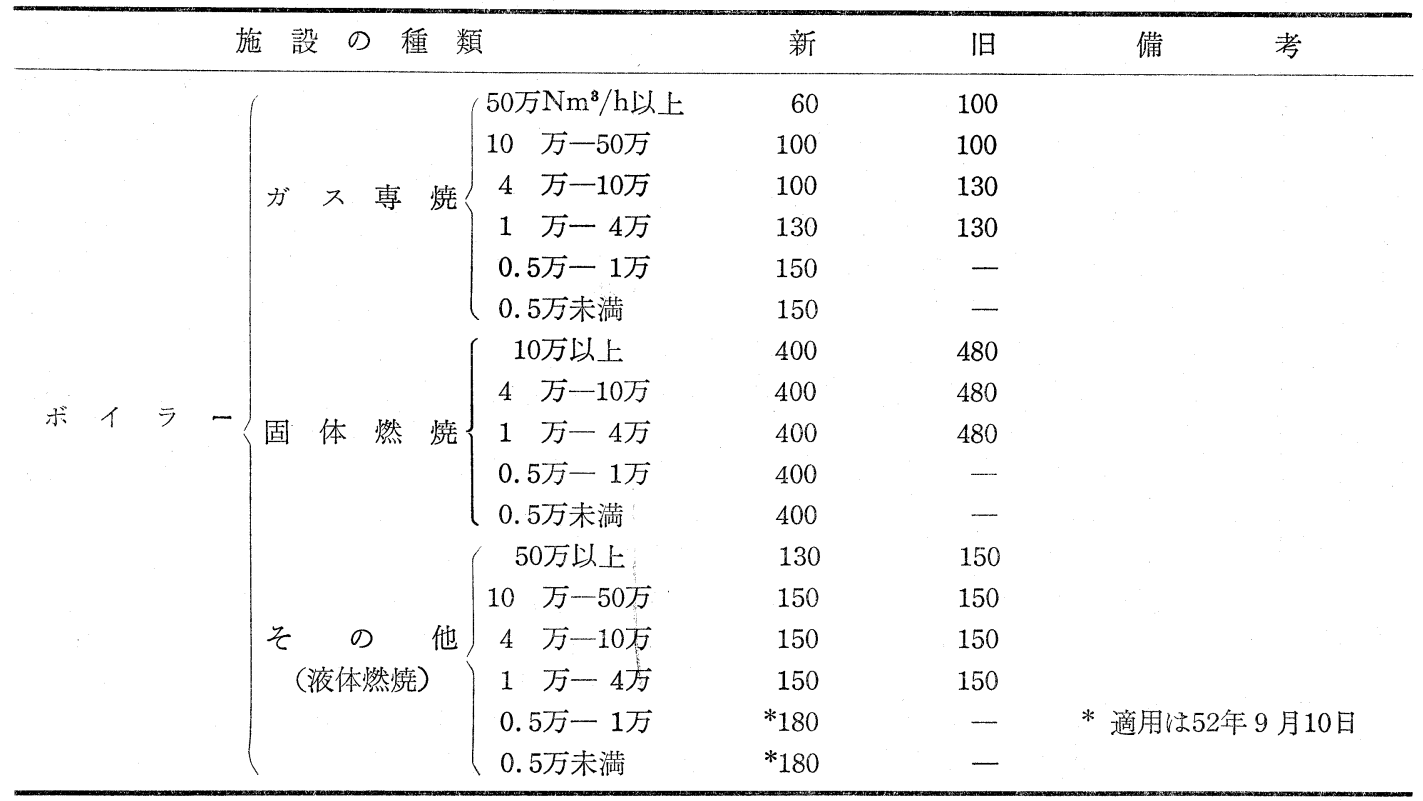

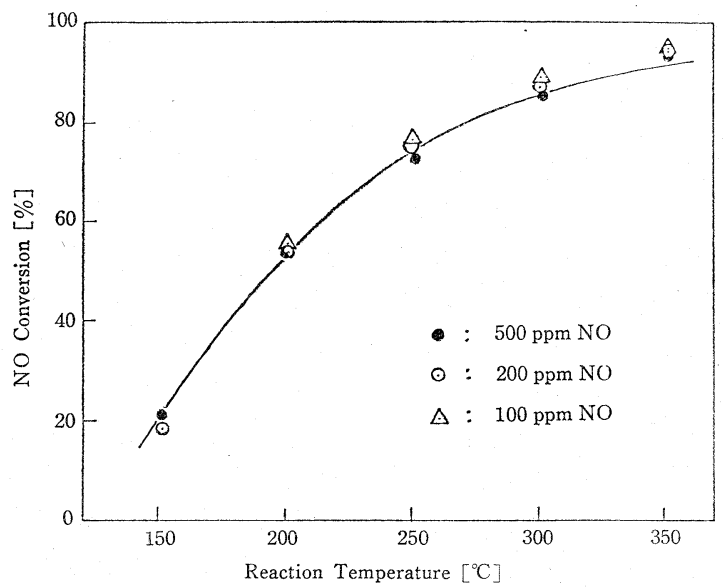

Catalyst ; NOXNON 600

Area Velocity; $20.4 \mathrm{Nm} / \mathrm{h}$

Gas Composition; NO 100 500ppm

$\mathrm{SO}_{2} \quad 250 \mathrm{ppm}$

$\mathrm{O}_{2} \quad 6 \%$

$\mathrm{CO}_{2} \quad 10 \%$

$\mathrm{H}_{2} \mathrm{O} \quad 10 \%$

$\mathrm{N}_{2} \quad$ balance

$\mathrm{NH}_{3} / \mathrm{NO}$ Mol. Ratio;

1.

图 6 Temperature dependence on NO-conversion

このことは当然のことながら，燃焼改善等によって

$\mathrm{NO}_{x}$ 濃度を出来るだけ低くして沶くことが好ましい ことを示して物り，図1亿示したケース 4 が完成され
たときは，それ単独では不充分であったとしても，畭

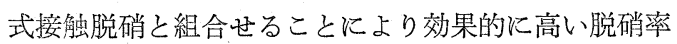
が得られるようになるであうら。 


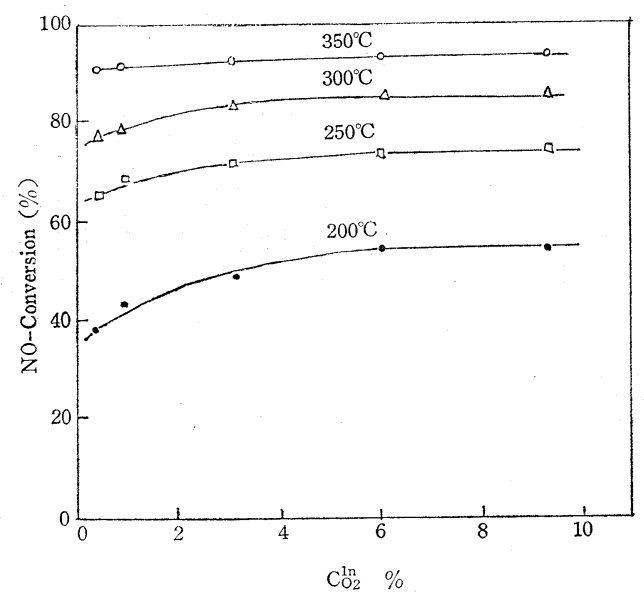

Catalyst

Reaction Temperature

AV

Gas Composition
NOXNON 600

$200 \sim 350^{\circ} \mathrm{C}$

$20.4 \mathrm{~m} / \mathrm{h}$

$500 \mathrm{ppm} \quad \mathrm{NO}$

500 ppm $\quad \mathrm{NH}_{3}$

$250 \mathrm{ppm} \quad \mathrm{SO}_{2}$

$0.4 \sim 9.5 \% \mathrm{O}_{2}$

$10 \% \quad \mathrm{H}_{2} \mathrm{O}$

$10 \% \quad \mathrm{CO}_{2}$

balance $\mathrm{N}_{2}$

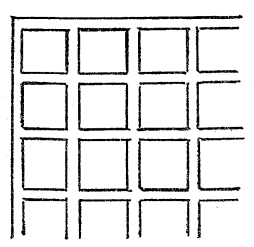

Honeycomb

(Ceramic)

(Grid Type)
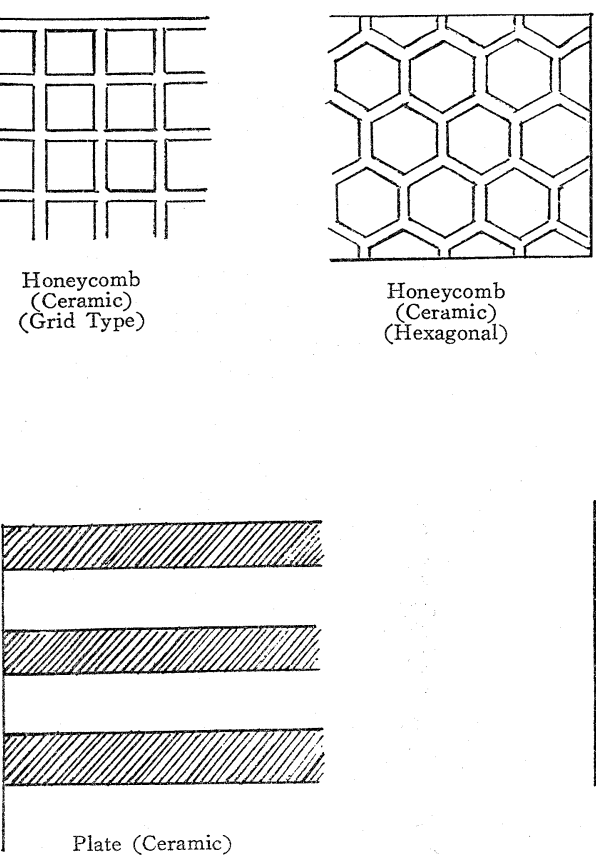

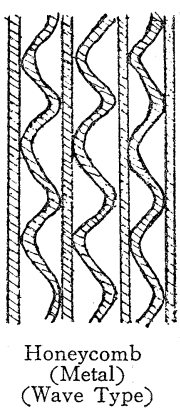

(Wave Type)
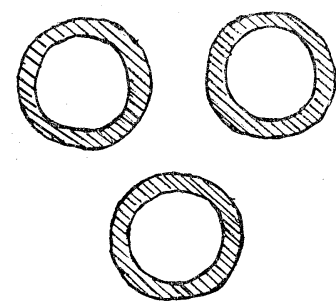

Tube (Ceramic)
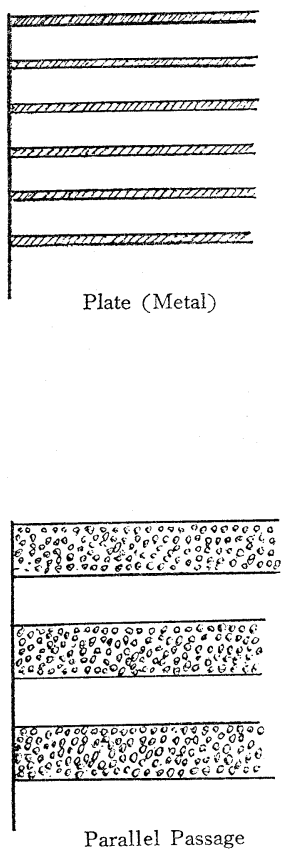

図 8 Cross section of parallel flow catalysts (actual sizes). 


\section{6. $\mathrm{SO}_{\boldsymbol{x}}$ と空気予熱器のトラブル}

脱硝に関し, 然料が石炭なるがために $\mathrm{SO} x$ が特に トラブルの原因になることはない。もちろん, $\mathrm{SO}_{x}$ 濃 度が高い場合には当然脱硝率に影響を与えるが ${ }^{17)}$ こ のことは燃料の種類には関係のないことである。

$\mathrm{NH}_{3}$ による $\mathrm{NO}_{x}$ の還元反応は, 裏返觉せば $\mathrm{NO}_{x}$ に よる $\mathrm{NH}_{3}$ の酸化反応である。従って使用される触媒 は酸化触媒であるとも考学られる。事実, 排ガス中の $\mathrm{SO}_{2}$ の一部は酸化されて $\mathrm{SO}_{3}$ になる。

一方， $\mathrm{NH}_{3}$ による脱硝法の実用化にあたって，未
反応 $\mathrm{NH}_{3}$ と排ガス中の $\mathrm{SO}_{3}$ によって惹き抗こされ るエアープレヒーターに拈ける酸性硫安析出による閉 塞及び腐蝕の問題 ${ }^{17)}$ がある。

ところが排ガス中に多量のダストを含む場合には， このダストが $\mathrm{SO}_{3}$ と反応吸収するため，排ガス中の フリーの $\mathrm{SO}_{3}$ は重油燃焼排煙より少くなる傾向にあ る。このことはダストによるセルフクリーニングと併 せ考えれば，プロセスケース $2^{7)}$ の場合はこの重要問 題は解消することになり，ケース 2 の方がケース 1 よ り有利であると考光る大きな理由である。

表 6 Specific surface area of catalysts

\begin{tabular}{|c|c|c|c|c|c|}
\hline & & & \multicolumn{3}{|c|}{ Specific Surface Area $\left(\mathrm{m}^{2} / \mathrm{m}^{3}\right)$} \\
\hline & \multirow{2}{*}{\multicolumn{2}{|c|}{ Dimension $(\mathrm{mm})$}} & Surfac & Area & Surface Area \\
\hline & & & $\overline{\text { Catalyst }}$ & Volume & Packed Volume \\
\hline \multirow{2}{*}{ Granule (Sphare) } & Diameter & & & & \\
\hline & \multicolumn{2}{|l|}{ 2010 } & \multicolumn{2}{|c|}{1,500} & 1,100 \\
\hline & \multicolumn{2}{|c|}{6} & \multicolumn{2}{|c|}{1,000} & 740 \\
\hline & \multicolumn{2}{|c|}{8} & \multicolumn{2}{|c|}{750} & 555 \\
\hline & \multicolumn{2}{|c|}{10} & \multirow{2}{*}{\multicolumn{2}{|c|}{600}} & 444 \\
\hline \multirow{7}{*}{ Tube* } & a & $\mathrm{b}$ & & & \\
\hline & 10 & 7 & & 350 & 405 \\
\hline & 15 & 10.5 & & 900 & 270 \\
\hline & 20 & 14 & & 677 & 203 \\
\hline & 25 & 17.5 & & 543 & 163 \\
\hline & 33 & 23.1 & & 410 & 124 \\
\hline & $\mathrm{a}$ & $\mathrm{b}$ & & & \\
\hline \multirow[t]{6}{*}{ Honeycomb } & 9 & 7 & & 866 & 437 \\
\hline & 10 & 7 & & 204 & 387 \\
\hline & 14 & 10 & & 908 & 278 \\
\hline & 20 & 14 & & 602 & 193 \\
\hline & $\mathrm{a}$ & $\mathrm{b}$ & & & \\
\hline & 7 & 5 & & 819 & 556 \\
\hline \multirow{4}{*}{$=$} & 10 & 7 & & 204 & 388 \\
\hline & 14 & 10 & & 909 & 277 \\
\hline & 20 & 14 & & 601 & 199 \\
\hline & $\mathrm{a}$ & $\mathrm{b}$ & & & \\
\hline & 8 & $60^{\circ}$ & & & \\
\hline & 10 & $60^{\circ}$ & & & \\
\hline & 12 & $60^{\circ}$ & & & \\
\hline & 14 & $60^{\circ}$ & & & \\
\hline & 8 & $120^{\circ}$ & & & \\
\hline & 10 & $120^{\circ}$ & & & \\
\hline & 12 & $120^{\circ}$ & & & \\
\hline & 14 & $120^{\circ}$ & & & \\
\hline \multirow[t]{5}{*}{ Parallel Plate } & Thickness & Clearance & & & \\
\hline & 1 & & & 000 & 320 \\
\hline & 1 & & & 000 & 220 \\
\hline & 8 & & & 250 & 125 \\
\hline & 10 & & & 200 & 91 \\
\hline
\end{tabular}

* Optimum separate packing

** Thickness mm constant（原報に追加挿入） 
もちろん $\mathrm{SO}_{x}$ が多いことは決して好ましいことで はなく，特に灰分の多い石炭排煙ではフォーリング指 数11)が大きくなり, 触蝶表面及び熱交換器への灰附着 傾向が増加するので，触媒の形状，反応の条件決定に あたって考慮を払う必要がある。

\section{7. 酸素含有量の問題}

石炭燃燒の場合，当然のことながら重油の場合にく らべて高い空然比が必要である。したがって排ガス中 飞含まれる残存酸素が多く, 発電量当りの排ガス量も 多くなる。排ガス量が多いといらことは，前述したよ らに経済的には不利で每るが，酸素含有量が高いこと は脱硝にとってはむしろ好都合でありまったく問題で はない17)。

図 7 亿残存酸素と脱硝率の関係 ${ }^{18)}$ の一例を示す。

\section{8. ダスト・スルータイプ触媒の評洒法}

一般に触煤の性能評価の指標として Space Velocity が用いられることが多い。

Space Velocity (SV)

$$
=\frac{\text { 処理ガス量 }\left(\mathrm{Nm}^{3} / \mathrm{h}\right)}{\text { 触媒の見掛忷体積 }\left(\mathrm{m}^{3}\right)}\left(\mathrm{h}^{-1}\right)
$$

この SV 值は反応装置設計上はきわめて重要な指数 であるが，触媒の性能を適格に示す值とはいい難い。 特に，ダストスル一型触媒に対しては不適である。粒 状の場合でも，大きさが異なれば同一触媒であっても 当然必要な $\mathrm{SV}$ 以異なって来るが，ダストスルー型の 場合はその影響が極端に大きくなるからである。従っ て我々は触媒の性能比較のための指標としては Area Velocity（AV）を用いている。

Area Velocity (AV)

$$
=\frac{\text { 処理ガス量 }\left(\mathrm{Nm}^{3} / \mathrm{h}\right)}{\text { 触媒の見掛け表面積 }\left(\mathrm{m}^{2}\right)}(\mathrm{m} / \mathrm{h}) \cdots \cdots(3)
$$

AVを使用すれば，触媒の型状の如何に拘らず，そ の性能を正確に比較することが出来る。

もちろん，設計上は SV が必要であることはいうま でもない。しかし，処理ガスの偏流を防止するため， ダストスルータイプの場合には，触媒層の前後に粒状 の場合にくらべて長い導入部が必要であるため, 反応 器の大きさに SVの比がそのままひびくわけではな い。

図 $8^{19)}$ に各種ダストスルータイプの触媒型状を, 表
$6^{19}$ ) 亿種々の型状の触媒の表面と体積の関係（Specific Surface Area）を示しておく。

\section{9. おわりに}

最後に以上述べたことを取りまとめると，

(1) 石炭燃焼排煙の脱硝は，高温電気集塵を予め行 った場合には，重油燃焼排煙の場合と特に異なる 点はない。

（2）高ダストのまま直接脱硝する場合には，触媒の 形状としてダストスルー型を選ぶと共に，ダスト によるアッシュカットを防ぐために，適当なガス 流速を選ぶ必要がある。

（3）今後の方向としては, 後流璣器類への灰附着等 を考慮し，経済的に見て高ダスト直接脱硝の方向 にむかうものと思われる。

\section{文献}

1) Esso Research and Engineering Co. USP. 341919, Feb. 12. 1974

2）日刊工業新聞，日本工業新聞，55．5．16

3）官公庁專門資料，12，(4)，1977

4) California Air Resource Boad 等の考光方

5) " $\mathrm{NO}_{x}$ Abatement for Stationary Source in Japan”, EPA 600/7-79-205

6）化学工業日報，54.9.8

7）日刊工業新聞，55. 5. 26

8）星沢注か，燃料協会誌 58，622，1979

9）未発表（日立造船撮影）

10）大野，公害と対策 16,1

11）高山，幸田，日立評論 60，11（1978）

12）未発表

13）未発表

14）官公庁専門資料，12，（4）1977

15）稲葉，燃料協会誌，57，618（1978）

16）長井ほか，日立造船技報，40，3（1979）

17）稲葉，燃料協会誌，57，618（1978）

18）長井注か，日立造船技報，40，3（1979）

19) 安藤淳平, “ $\mathrm{NO}_{x}$ Abatement for Stationary Sources in Japan" Interagency Energy/Enviroment. R\&D Program Report, EPA 600/7-79205 August 1979 


\title{
NO $x$ Removal from Flue Gas of Coal Burning Boiler
}

\author{
Hideya INABA
}

(Special Advisor, General Manager of Clean Air System Development Department Hitachi Shipbuilding \& Engineering Company Limited)

SYNOPSIS : - When coal is used for boiler fuel, from a viewpoint of environmental problem especially laying emphasis on NOx removal of flue gas, there are many points of difference and noteworthy matters as compared with heavy oil fuel.

Most important points are that dust concentration is very high and fly ash characteristics are remarkably influenced by kind of coal.

Attention to these points, the countermeasures are described in priority. 